\title{
Trans-Border Trade, Minerals, and Civil War Impacts on Land Use and Land Cover Change in GOMA, Eastern Congo: An Integrated Geospatial Technologies and Political Economy Approach
}

Onyumbe Enumbe B Lukongo*

Southern University and A \& M College, Baton Rouge, LA, USA

Received: December 30, 2017; Accepted: January 16, 2018; Published: February 14, 2018

*Corresponding author: Onyumbe Enumbe B Lukongo, Southern University and A \& M College, Baton Rouge, LA, USA, E-mail: onyumbe_lukongo@subr.edu

\begin{abstract}
This study analyzes land cover and land use change in the territory of Goma, Eastern Democratic Republic of Congo by leveraging the geospatial technologies capabilities (Remote sensing, GIS, and Cartography) and the analysis of existing literature on the political economy of war. The Normalized Difference Vegetation Index (NDVI) derived from Landsat Enhanced Thematic Mapper plus images were used to detect changes between 1987 and 2010. Results suggest that changes in the landscape of Goma are attributable to institutional factors such as the trans-border trade networks, the refugee influx of about 1.5 to 2 million due to ethnic conflicts in Rwanda, the Congolese civil wars, and the operations of international nongovernmental organizations and humanitarian agencies. An increase in non-vegetation areas is evident in the territory of Goma. Overall, economic opportunities, humanitarian and NGOs operations and mineral trade create more wealth in the region. This is evidenced by massive investments in real estate and unusual population growth. The study expands the applicability of both geospatial techniques and political economy by shedding new lights on the interplay among war, minerals, and land cover and land use change.
\end{abstract}

Keywords: Geospatial technologies; Remote sensing; GIS; Civil war; Minerals; Political economy;

\section{Introduction}

This study applies an integrated approach to assessing the land cover and land use change in the district of Goma located in eastern Congo. Existing studies do not systematically utilize the capabilities of the geospatial technologies (Remote sensing, GIS, and Cartography) and the knowledge accumulated in the political economy of war to address the issue of land cover and land use changes in a small geography such as the territory of Goma. The specific contribution of the study is to connect the missing link between the geospatial technologies and the political economy of war using a mixed methods approach. Borrowing the definition of Political Economy from Mill ([27], p.31), it is necessary to understand that Political Economy is about wealth as unequivocally stated by this great economic thinker that:

...Writers on Political Economy profess to teach, or to investigate, the nature of Wealth, and the laws of its production and distribution: including, directly or remotely, the operation of all causes by which the condition of mankind, or of any society of human beings, in respect to this universal object of human desire, is made prosperous or the reverse.

This study includes the analysis of the political economy in order to understand how wealth is created, maintained, and distributed. The best effort is to leverage the capabilities of the geospatial technologies in bi-temporal spectral change detection of land cover and land use between 1987 and 2010 and the analysis of the environmental, political, economic, and social contexts of Goma. Turner ([40], p.2) notes that

International negotiations led to a formal peace in 2003 but a welter of Congolese and foreign groups continued to struggle to control eastern Congo and its mineral wealth. The conflict in DRC became known as the deadliest since World War II. DRC supposedly was the rape capital of the world. "Conflict Minerals" were said to be financing the armed groups ...

At this stage, it is worth defining the concepts of land use and land cover. Several definitions have been proposed in the literature, but this study adopts the definition suggested by Lillesand and coauthors. Lillesand, et al. ([24], p. 213) define land cover as "the type of feature present on the surface of the earth," represented by, "cornfields, lakes, concrete highways." These authors define land use as "the human activity or economic function associated with a specific piece of land." Why years 1987 and 2010 were chosen? The choice for 1987 was dictated first by the quality of the data, cloud-free image and second because 
there is no record of ongoing armed conflicts in the district at that time. Again cloud-free image was acquired for the year 2010. This year was chosen to capture changes resulting from massive refugee's influx from Rwanda, internal displaced individuals, armed conflicts, and wealth accumulated from minerals and reinvested in the real estate.

To provide context and content to factors leading to land cover and land use change, this study analyzes the existing literature on the political economy of war in Congo with a sole purpose of finding explanations for the land use and land cover change. In fact, this analysis is closely associated with a search and discovery of meanings, intentions, consequences and context.

It goes without saying that the 1994 Rwandan genocide led mass migration of between 1.5 and 2 million refugees to Congo alone especially to the Kivu province (United Nations High Commissioner for Refugees, 2017). Goma, Masisi, and Rutshuru territories in Congo attracted the majority of the refugees according to the 2009 United Nations High Commissioner for Refugees' Statistical Yearbook. Figure 1 displays the number of refugees coming to Congo from Rwanda as recorded by the UNCHR from 1994 to 2010. A caution is in order here because these figures only capture individuals who registered with this UN agency to get shelter, protection, and assistance on the refugee camps.

\section{Refugees from Rwanda hosted in Congo , 1994-2010}

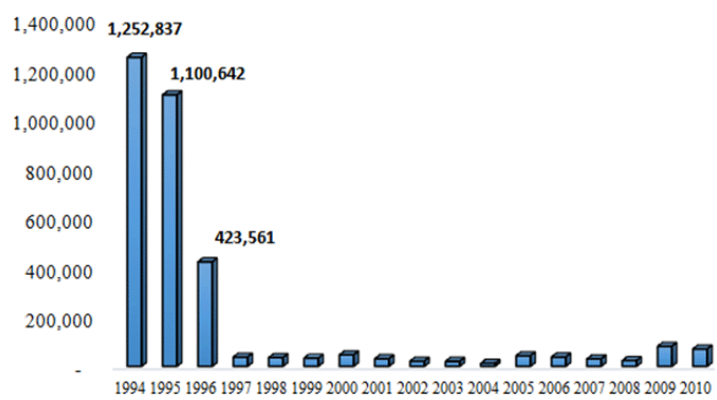

Figure 1: Number of Refugees from Rwanda to Congo from 1994 to 2010.

Source: UNCHR population statistics time series

http://popstats.unhcr.org/en/time_series

The September 1996 joint attack of Hutu refugee camps resulted in spread of refugee population in North and South Kivu. The flow of internal displaced persons (IDPs) continued to other provinces as the rebellion was moving westward to overthrow Mobutu regime in May 1997 (Nzongola-Ntalaja, [29] p.225; Turner, [40], p.2; Raleigh and Hegre, [32]). Eastern forest areas including the Virunga National Park (VNP) experienced tremendous pressure as population expanded (United Nations Environment Programme Centre World Conservation Monitoring 2010; Draulans and Van Krunkelsven, [13]; Butsic, et al. [3]). During 1998-2003, a new war erupted as a result of deterioration of relation between Kabila regime and its allies, Rwanda and Uganda (Hayes and Burge, [19]). This war was a result of a complex mix of foreign occupation, several rebel groups, and fierce competition to take control over minerals (Institute for Environmental Security, [20]; Turner, [40], p.2). In reporting on "A Results-Based Vision for Conservation in Central Africa," The U.S. Fish and Wildlife Service, [42] note that:

The damaging effects of unregulated mining in Central Africa can be seen in Kahuzi-Biega National Park in eastern DRC. Mining for columbium-tantalite (coltan) destroyed significant amounts of gorilla habitat and is considered by some to be a primary motivation for war among rival militias. Both people and wildlife have suffered as a result of the DRC's difficulty in managing and controlling access to its mineral-rich forests, which make up about 80 percent of the world's known deposits of coltan, a metal ore widely used in the production of mobile phones and other electronic devices. ...Recent acoustic exploration in Lake Edward in Virunga National Park, DRC, posed a risk to species such as the hippopotamus, whose numbers have been slowly increasing since a drastic 98 percent decline that began in the 1970s. The risk of oil spills and industrial waste pose additional potential threats to marine and freshwater life.

High demand for columbite-tantalum (coltan) at the global market puts more pressure on the supply chain of minerals (Institute for Environmental Security, [20]; USGS, [46]). At the same time, humanitarian operations helped open forest areas including the Virunga Park for refugees. Also, notice that future contracts and mineral proceeds put more wealth in the region.

At this stage, it is time to pause and ask the main questions of this study: (1) What are the driving forces of local land cover and land use change transformation in the territory of Goma? (2) What are the possible connections between land cover change and the economic, social, political, and environmental conditions? (3) What are the local activities which change land cover and land use in the territory of Goma? To answer these questions, the study analyzes the role of trans-border trade networks, the geography of Goma, the presence of valuable natural resources in eastern Congo and its connection with political instability, insecurity, and civil wars, and the presence of humanitarian organizations, donor agencies, and nongovernment organizations.

To respond to the above questions, the study pursues two main objectives. First, it detects and maps out the land cover change using the normalized difference vegetation index (Campbell and Wynne, [4], pp.445-447). Second, it analyzes and identifies institutional factors (Lambin, et al. [22]) which may perhaps affect the land cover and land use change in the territory of Goma. The rest of the study is organized as follows. Section 2 gives a brief review of related studies. Section 3 presents the methods while Section 4 discusses the findings. Finally, Section 5 provides the overall conclusions and briefly discusses some leads for future research.

\section{Related Studies}

Since the inception of human society, scarcity has been a common problem each society faces regardless of its level of development. In discussing factors that likely contribute to 
land-use and land cover change at local level, Lambin, et al. [22] provide a list of four synergetic factors: (i) changing opportunities created by the markets, (ii) outside policy intervention, (iii) loss of adaptive capacity, and (iv) changes in social organization and attitudes. At the global stage, other studies report changes in land cover and land use driven by human activities (Auch, et al. [1]; Zaidi, et al, [53]; Butsic, et al, [3]) as one of the driving forces of land cover and land use change around the world. These activities range from exploration and exploitation of gas and oil (Duncan, et al. [15]; Yu, et al. [52]), dramatic social change (Vlassenroot and Büscher, [47]), urbanization (De Sherbinin, et al. [10]), forest exploitation (Draulans and Van Krunkelsven, [13]; Carr, [5]), mineral resources exploitation (Hayes and Burge, [19]; Institute for Environment Security, [20]), and shelter for refugees and internally displaced persons (United Nations Environment Programme World Conservation Monitoring Centre, 2010), to biophysical forces that may drive land use and land cover change (Lambin, et al. [22]).

Research suggests that the major causes of conflicts in Congo include poverty, uneven development, colonial legacy, ethnical rivalries, weak institutions, corruption, and geography (Wallensteen and Sollenberg., [49]; Wallensteen and Sollenberg, [48]; Collier, [7]; Collier and Hoeffler, [8]; Easterly and Levine, [16]; Olsson and Fors, [30]). It is reasonable to argue that the onset of armed conflict and its continuation should find some conditions ready for the conflict or violence eruption. Given some other factors, recent violent conflicts in the eastern Congo constitute an example of the dark side of globalization, transborder trade networks, and "lootable resources" as described in Ross $([34,35])$. Abundant evidence is available in conflict and peace literature for similar situations around the world and in the African continent. The most cited examples are Sierra Leone (diamonds), Angola (oil, diamonds), Sudan (oil)... (See Ross, [35]; Dena, [11] for more details).

In recent history of the Democratic Republic of Congo, the 1994 Rwandan genocide, the subsequent transborder political instability and Congolese civil wars have impacted the environment (Draulans and Van Krunkelsven, [13]), land cover and land use in different territories affected by these atrocities and insecurity. Lambin, et al. [22] stresses people's responses to economic opportunities as driving force of land cover change by insisting on the catalyst role of institutional factors. These authors express the role of global forces for amplification and attenuation of land use change. According to De Sherbinin, et al. [10], the view of land cover and land use change is contextual and location specific due to the uniqueness of each case understudy. They also document some applications of remote sensing in social studies such as demography, human health and epidemiology, archaeology and anthropology, international relations, law and policy, land-use change and sustainability trajectories, and urban studies. Since the application of the Remote Sensing in Political Economy is missing, the study is the first to open the avenue for further studies by combining these two fields.

Gallant, et al. [17] cite the internal increase and movement of the human population as the explanation of the land use change, but it is reasonable to argue that this movement for the case of Goma is driven by civil wars, insecurity and ultimately by control of supply of natural resources and the trans-border trade of natural resources and smuggling and real estate investments.

In following Napton, et al. [28], the study is applied to the smallest administrative boundary, which is the territory of Goma. Note that Gallant, et al. [17] stress that the importance of the local aspect of the land cover change in order to accurately interpret changes and provide explanations of the observed changes in land cover and land use in the area of interest. Trans-border trade, civil wars and political instability spilled over the neighboring countries in some Sub-Saharan Countries (Uganda, Liberia-Sierra Leone, and Congo-Rwanda, Angola-Congo). The United Nations Environment Programme World Conservation and Monitoring Center argues that the warfare of 1998 up to now in east Congo may explain the land cover and land use in the Virunga Park. The study covered a large scene acquired from the Landsat 7 ETM+ using path 173 and row 61 with a focus on the deforestation of the park. The path-row grid system will be explained in the next section related to the methods. The present study complements the existing literature with a local and a lowest administrative geographic unit in Congo, which is a territory-level analysis. This is the first study connecting the land cover and land use change and the political economy of war.

\section{Methods}

The section discusses the mixed methods approach (Creswell and Clark, [9], p.2) applied to this study, that is, the research design as well as data collection and analysis. The mixed methods approach allows for a combination of the geospatial technologies (Remote Sensing, Cartography and GIS technologies) and the analysis of the political economy war in eastern Congo. It is the first attempt in the literature. This study strategically applies the analysis of existing studies on political economy of war as a means of gaining insights on conditions that induce changes observed on the land cover and land use in the territory of Goma. The chosen approach provides more strength to the overall study and expands the applicability of the geospatial technologies to the field of political economy at the local level. The study nurtures the mixed methods approach based on the complexity of the subject under study. This investigation would help evaluate the spatial consequence of wars and mineral trading on the landscape of Goma. These forces put pressure on limited local resources and lead to wealth creation and assets building from minerals (gold, tungsten, uranium, oil, natural gas, columbite-tantalum or coltan, cobalt etc.), illegal trade, and humanitarian and NGOs operations. Goma is nowadays a node of land and air transportation networks in eastern Congo, a business hub where monies flow from warrelated goods, future contracts, mineral trade, and humanitarian operations.

\section{Research Design and Study Area}

\section{Research Design}

The research design (Bernard, [2], p.104) as presented here involves decisions made for data need assessment, data collection 
and pre-processing, data analysis, and the interpretation of the results. Based on the nature of the issue addressed by this study, it is imperative to approach this study within a mixed methods approach, which is according to Creswell and Clark, ([9], p.2) a harmonious combination of the quantitative and the qualitative methods. The quantitative aspect of the study allows for the data collection through remote sensing technologies, data processing through both remote sensing and GIS and Cartography for the mapping of changes observed between 1987 and 2010. It should be noted that the qualitative portion of this study provides context and explanations of how physical and institutional forces contributed to changes observed in land use and land cover in the territory of Goma. The reason for choosing mixed methods approach is that either quantitative or qualitative approach by itself cannot adequately help understand the context and the content of the land cover and land use change in the region. The synergy gained from both methods allows researchers to accomplish the research objectives and paves the way for an emerging subfield of inquiry, geospatial technologies and political economy.

\section{Brief Description of the Study Area}

Figure 2 provides the location of the study area on both Africa's and Congo's maps. Reading from the top left panel of the figure, one finds the position of Congo on Africa's map and the very bottom portion displays in full scale the territory of Goma. The latter is located about middle portion of Congo's map going easterly. Based on its relative location, note that Goma is 20 kilometers away from Nyiragongo Volcano. The downtown area and the commercial districts are located at a lower elevation. The airport and other nearby residential areas in the outskirt are at a higher elevation. Lake Kivu is located in the southeast of Goma. Evidence from the map analysis and the author's local knowledge of the region add values to this study.
Based on its geographic coordinates, Goma is located between $1^{0} 41^{\prime}$ S latitude (-1.6771 degrees minutes) and $29^{\circ} 15^{\prime} \mathrm{E}$ longitude (29.242 degrees minutes). The territory of Goma was selected due to its actual economic and political role and a remarkable transformation since the 1994 Rwandan genocide. This territory of Goma is located in the "Columbite-tantalum belt" or locally called "Coltan belt", which goes from upper North east Bunia, Orientale Province to Goma, North Kivu, to Bukabu, South Kivu and to Maniema Central East Congo down to Katanga southeast Congo. Based on its physical and chemical properties, tantalum has been used in the production of cellphones, hearing aids, and computer hard drives to name a few. The city of Goma's growth may be explained by its role as a borderland and frontier city (Vlassenroot and Büscher, [47]) with an international airport. Goma is also a business and mining trade center, an air hub, a place for opportunity, a shelter for refugees and internally displaced persons, and a political and military siege of rebel groups.

To understand the local dynamics, let add two nearby territories to the overall picture. Recently, in a report entitled "Mineral supply chains and conflict links in eastern Democratic Republic of Congo: Five years of implementing supply chain due diligence," the Organization for Economic Cooperation and Development (2015) estimates about 550 mining sites very close to Goma. For the sake of clarity, let look at the bottom part of the left panel of Figure 2, one would see that the territory of Rutshuru is located east of the territory of Goma and the territory of Masisi is located west of the territory of Goma. Based on the geographic coordinates, the territory of Masisi is located between $1^{0} 24^{\prime} \mathrm{S}$ latitude and $28^{\circ} 48^{\prime} \mathrm{E}$ longitude. It is a ranch, a farmland and a mineral rich territory. This territory hosted many refugees during the 1994 influx of Rwandan refugees and internal displaced Congolese during the first and the second civil wars. Looking east, the territory of Rutshuru is located between $1^{0} 11^{\prime}$ S latitude

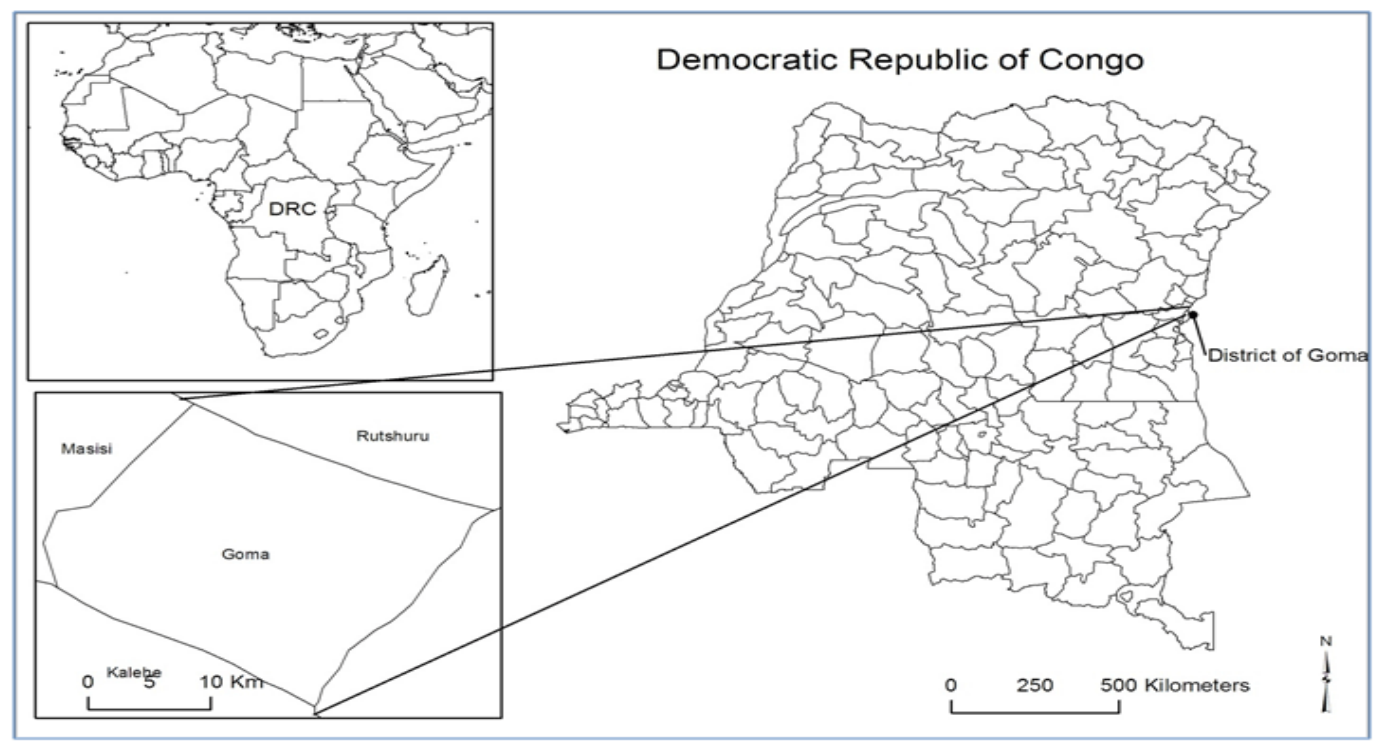

Figure 2: NStudy Area: Territory of Goma 
and $29^{\circ} 27^{\prime} E$ longitude in the Great Rift Valley. This territory is also known as a shelter for refugees and internal displaced persons. It is also the place where the Virunga National Park is located. This park is the greatest biological diversity of any park in Africa and world heritage in danger in 1994 according to the 2010 United Nations Environment Programme World Conservation Monitoring Centre report. The territory of Rutshuru has one of the most valuable mineral resources of Congo. The Lueshe mine in north of the town of Rutshuru is one of the world's biggest reserves of pyrochlore, an ore of niobium. This ore is used in the production of jet engines, gas turbines, turbocharger systems, a medium for rocket subassemblies, and a critical input for several medical devices. Goma is the main nearby city.

\section{Data Acquisition}

The United States Geological Survey (USGS, thereafter) has the official mandate from the Land Remote Sensing Policy Act of 1992 to archive, maintain, and distribute two types of data products. The data used in this study come from the Landsat 7 Enhanced Thematic Mapper+. This spacecraft has a 16-day repeat coverage of the same area to be imaged. Figure 3 obtained from the 2007 Department of the Interior USGS-NASA Landsat 7 Program report provides a schematic representation of the Landsat 7 ETM model that includes its sensors, electric power system, telecommunications system, attitude control system, and attitude reaction system.
The first type of data product (Level 0R) is unprocessed image data with no radiometric or geometric corrections. The latter were made during the data pre-processing stage. It should be noted that data requesters only bear the burden of fulfilling user request form. The second type of data product at premium has radiometric or geometric corrections. Once the access is granted by the USGS, researchers shall determine the path and the row of the study area in order to obtain the satellite image of the area of interest. Because the USGS utilizes the World Reference System, which has path-row grid system linked to its database to facilitate data product retrieval and distribution. The database maintained by the USGS has path-row attributes related to each scene. Figure 3 shows the global model of the USGS called the World Reference System path-row grid for each scene area. Data requesters should have gathered the latitude and the longitude either defined in degrees, minutes, and seconds or in degree decimals for the area of interest to facilitate data acquisition. Satellite survey data or remotely sensed data belong to the raster data model with a geographic primitive called pixel. The latter is the basis of the grid of cells system (Thurston, et al. [39], p. 171; Chang, [6], p.68). Each cell is represented by a row when reading east-west and a path when looking north-south. The area of interest is defined by a row and a path to be situated on the global map as shown on Figure 4.

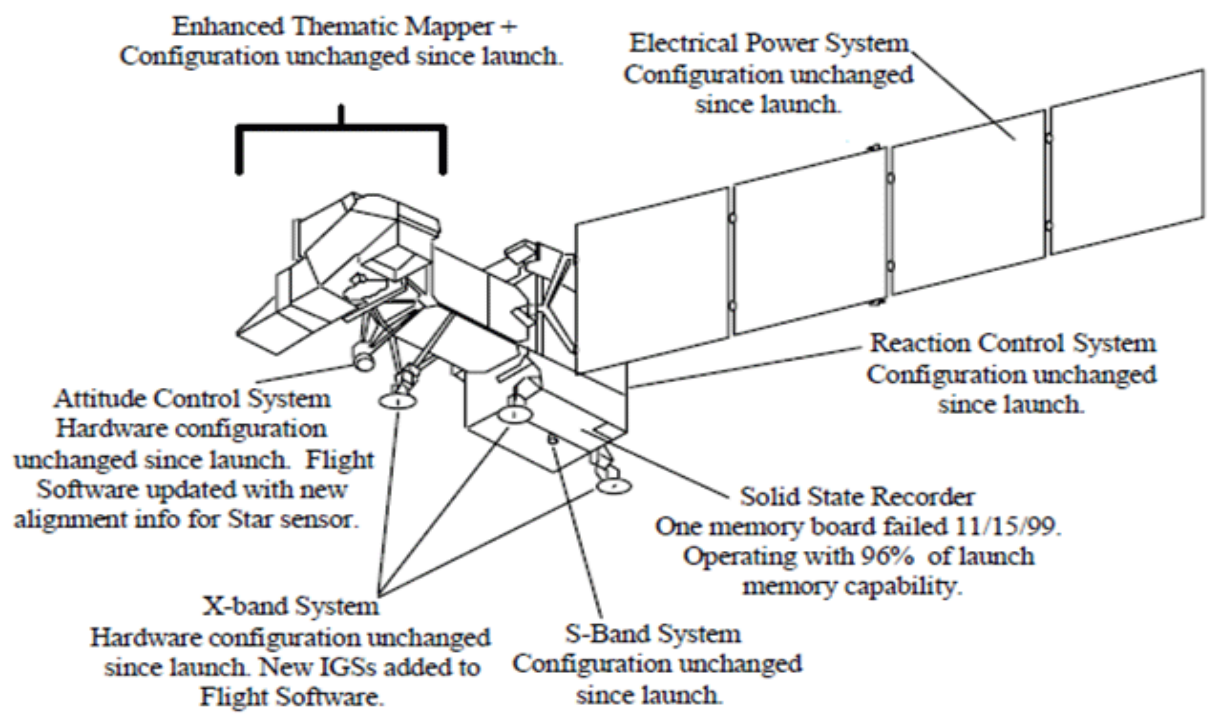

Figure 3: Landsat 7 ETM Model

Source: U.S. Department of the Interior USGS-NASA Joint-Annual Report of 2007

Figure 4 summarizes the grid system used by the USGS to gather remotely sensed data for each earth's scene. It helps one visualize the concept of the World Reference path-grid system.

As for the data acquisition and data processing, latitude of -1.6772 degrees-minutes and a longitude of 29.242 degrees- minutes were applied to uncover the geolocation of the territory of Goma. It can be identified through path 49 and row 183.

After a brief description of the global grid system, let summarize the architecture of the Landsat 7 on Figure 5. It outlines its mission planning, ground centers and stations, 
describes the flow of information, data acquisition, data processing, data archiving, and the distribution of data products to end users. This puts into perspective different phases from the remotely sensed data acquisition to the distribution of the data researchers. A visual examination of the figure provides more details.

Pursuing the groundwork, one of the challenges faced by researchers is the interference of the atmospherics. Cloud cover often undermines the quality of remotely sensed data. This study acquires several images and selects the best images, which are cloud-free. The latter are available in September, which coincides with the end of the dry season. The wet or rainy season runs from May to October and the wet season goes from June to September. Both Landsat TM images of 1987 and 2010 were acquired during the same month for the sake of comparison. It is a standard practice in the applied geospatial research to gather images during the same period time in order to minimize some discrepancies (Lv, et al. [26]; Wingate, et al. [51]).

\section{Image Classification and Detecting Changes in Land Cover and Land Use}

\section{Image Classification}

The review of existing studies indicates various techniques with advantages and shortcomings for assessing land use and land cover change. Two approaches are popular in the literature: (i) comparative analysis of independently produced classifications and (ii) simultaneous analysis of multi-temporal data. This study employs an unsupervised classification along the local knowledge of the study area and the map analysis to improve the accuracy of the observed spectral classes. Based on the standard practice in geospatial research, the supervised classification is guided by data collected on the study area as the initial step for grouping data into different classes. Supervised classification was not feasible for the obvious reason of security concerns in the study area. Consistent with Campbell and Wynne ([4], p.138, 340), the classification strategy adopted for this study is appropriate in the sense that (i) it minimizes errors in grouping data into different classes, that is, the unsupervised classification is that spectral classes are obtained automatically as opposed to the supervised classification where classes in some cases may not be noticeable by researchers; and, (ii) the knowledge that the researcher brings to the analysis based his familiarity with the study area and the purposeful effort to conduct map analyses of the existing literature add value to the content and context for the present image interpretation.

A remote sensing study related very close to the study area was conducted by Potapov, et al. [31] who produced a decadal forest change map for Virunga National Park. Results indicate human activities as the leading cause of deforestation. However, the present study has a different approach and focuses on the territorial level which is the smallest administrative boundaries in Congo. This strategy has been effective in similar applications as described in Gallant, et al. [17]. The standard procedures related to unsupervised classification are organized around the four major steps. The ERDA Imagine and ESRI ArcGIS packages were employed to complete the following tasks. First, the researcher chooses the way to display the Landsat image as a raster layer using the three basic colors red for band 4 , green for band 2 , and blue for band 2 by adjusting the layout of image to fit the computer monitor frame. The second task is to convert the Landsat image (raster data/layer) to a shapefile (vector data/layer). The main purpose is to obtain a separate map of the territory of Goma from the entire scene captured by Landsat based on the defined path and row. The acquired image was large than the study area. A clip operation was conducted in ArcGIS Map to create a shapefile of the territory of Goma also called the area of interest. The third task is to subset the Landsat image to the area of interest. Researchers shall ignore zeros in output statistics. Once the Landsat image of Goma is ready, the actual task consists of the unsupervised classification, which was conducted using the Landsat 7 Normalized Difference Vegetation Index (NDVI). To complete the last task, researchers should define the number of classes and thereafter assign colors to land cover classes. As for this study, five land cover classes have been used following Dent, ([12], p.143) practical advice suggesting between four and six classes for the readability of the map. The same procedures were applied to both Landsat images of 1987 and 2010, respectively. Given that the data acquisition and pre-processing have been clarified, the next step consists of the change detection.

\section{Bi-Temporal Spectral Change Detection}

Following Campbell and Wynne ([4], p.446), the study adopts two techniques: (1) the visual interpretation and (2) image algebra consistent with the main objectives. As the study focused on two remotely sensed images, it is necessary to outline for the sake of research efficiency and clarity steps leading to effective bi-temporal spectral change detection. Prior to that, it should be emphasized that at the very minimum the two satellite images for the study shall have been acquired at the same time, the month of September and from the same sensors, that is, the Landsat 7 ETM+. Also, in the spirit of Campbell and Wynne ([4], p. 446), researchers shall do the following: first, define the projection of 1987 and 2010 satellite images to the Universal Transverse Mercator projection system using the UTM projection imbedded in the shapefile of the territory of Goma built in ESRI ArcGIS Map platform and display both images side by side as shown in Figure 6 (the NDVI of 1987 is displayed on the left-hand side of the figure while the NDVI of 2010 is displayed on the right-hand side.) and second, proceed to image differencing, which is an arithmetic operation in order to detect changes in terms of non-vegetation areas using the Normalized Difference Vegetation Index (NDVI).

The NDVI profile has been employed in the literature to monitor phonological patterns of the earth's vegetation surface and to identify ecoregions to name a few (Lunetta, et al. [25]; Campbell and Wynne, [4], p.446). The NDVI is written as:

$$
N D V I=\frac{\rho_{\text {nir }}-\rho_{\text {red }}}{\rho_{\text {nir }}+\rho_{\text {red }}}
$$

Where $\rho_{\text {nir }}$ and $\rho_{\text {red }}$ are near infrared and red bands, respectively. The NDVI values range from -1 to 1 . Five classes were 


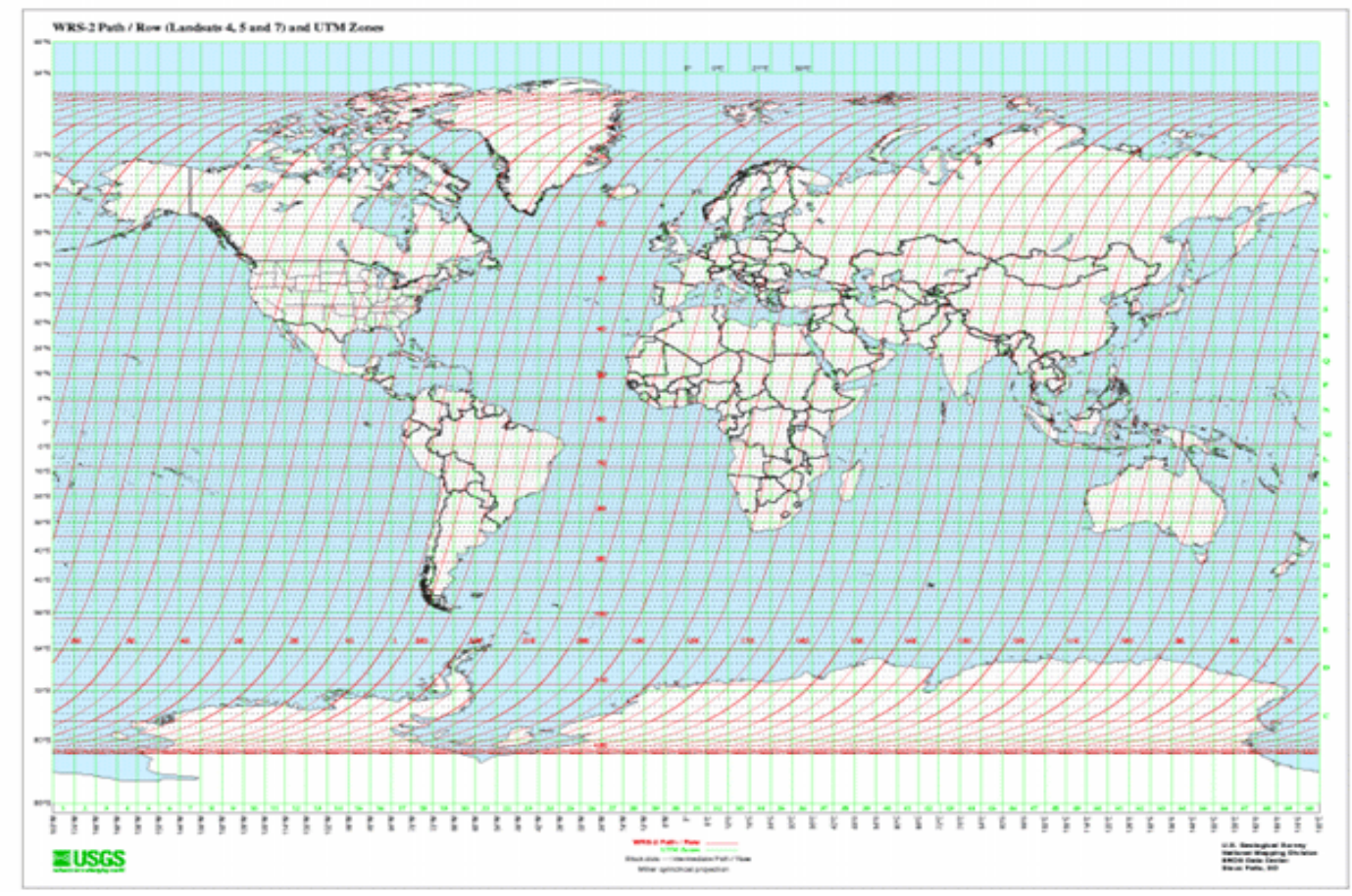

Figure 4: USGS World Reference System path-row/grid

Source: U.S. Department of the Interior USGS-NASA Joint-Annual Report of 2007

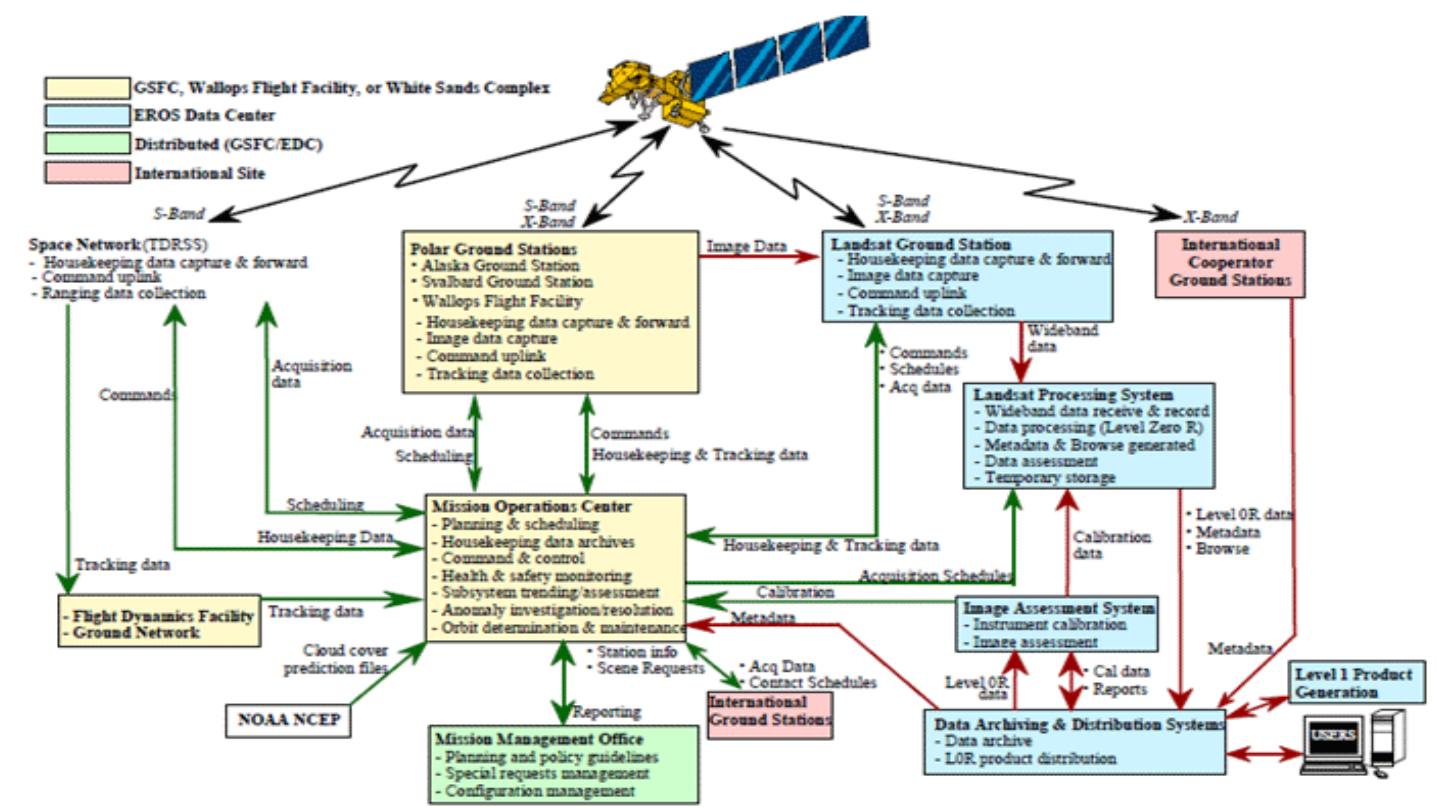

Figure 5: Architecture of Landsat 7 program from the inception to users.

Source: USGS 2007 Landsat 7 Program Annual Report 


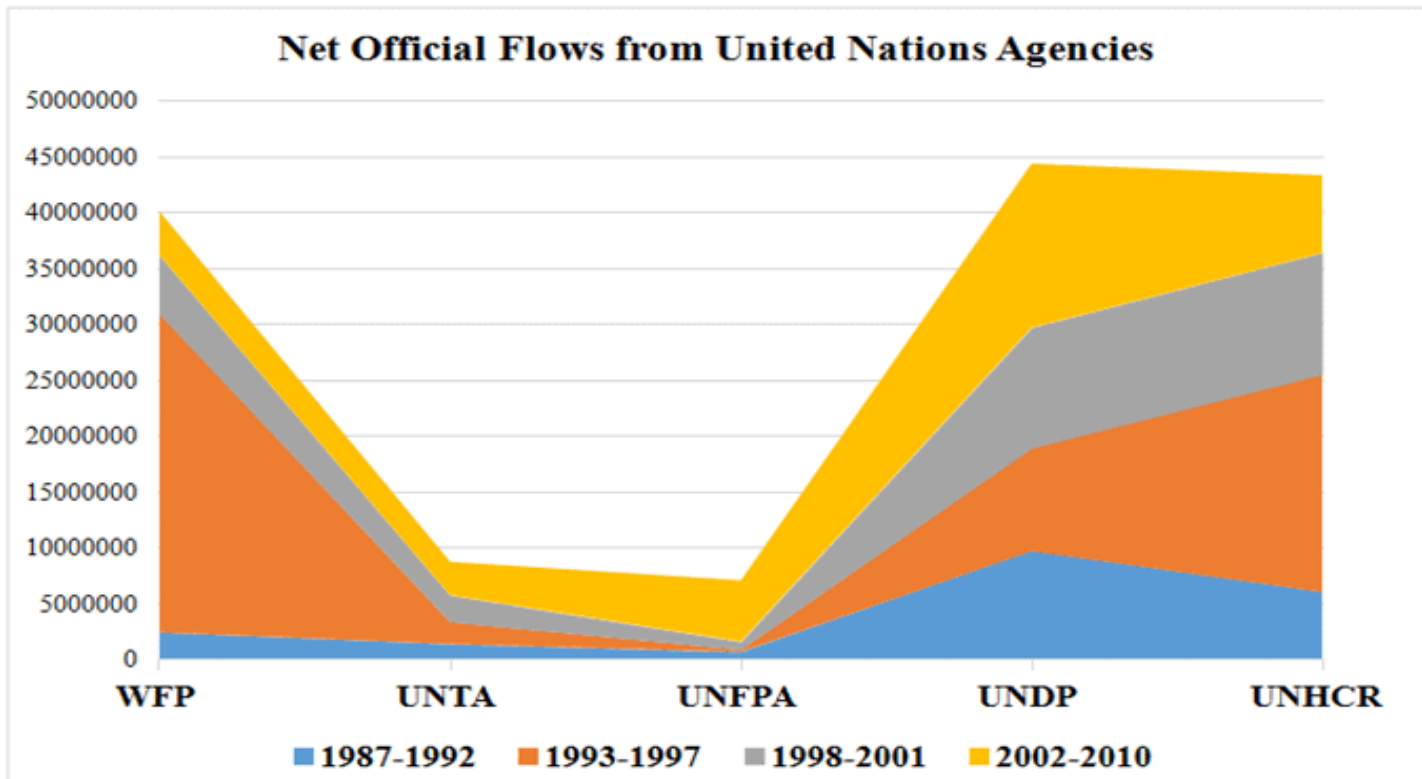

Figure 6: Average Net Official Flows from the United Nations Agencies, 1987-2010.

Source: The World Bank Data on net official flows from United Nations' Agencies to the Democratic Republic of Congo, 1987-2010(available at https:// data.worldbank.org/country/congo-dem-rep).

Note: WFP stands for World Food Program; UNTA stands for United Nations Transitional Authority; UNFPA stands for United Nations Population Fund; UNDP is the United Nations Development Program; and, UNHCR is United Nations High Commissioner for Refugees.

created to map out the NDVI ranging from -1 to 0 (build up land, bare soil land), $0-0.1,0.1-0.2,0.2-0.3$, and $0.3-1$ (agriculture and forest land) as shown on the legend associated with Figure 5. As said early on, these classes were created to emphasize the difference between the land cover and land use types. There is no clear guidance in the literature related to optimal number of classes. The map analysis of the resulting NDVI maps of 1987 and 2010 documents changes observed in the land cover and land use in the territory of Goma. Additionally, the change in acreage was calculated from classes that have more than 0 between 1987 and 2010 to measure the land cover and land use change. Results are presented in the next section.

\section{Results}

This section summarizes the main findings. To put results into context, it is important to note that there are about 150 humanitarian organizations present in Goma, more than 200 mines, and over 50 rebel groups in the region. However, the data on their economic impacts are not readily available to researchers. The Congo is not an exception among developing countries where economic statistics (production, employment, etc.) at the local levels are inexistent. Further research is still needed in this area. Given this state of affairs, I instead utilize the data that I gathered from the World Bank on the net official flows of fund to the Congo from United Nations' agencies. The latter are the World Food Program (WFP), the United Nations Transitional Authority (UNTA), the United Nations Population Fund (UNFPA), the United Nations Development Program (UNDP) and the United Nations High Commissioner for Refugees (UNHCR). Evidence suggests that more 70 percent of long-lasting violence occur in the eastern
Congo. This implies that most of the hard currencies are at least spent in the region. Goma has an important geopolitical and economic position.

Figure 6 presents the average of net official inflow of funds to the Congo from the U.N. agencies are organized in four periods. The y-axis reports funds in dollars and the $\mathrm{x}$-axis displays the U.N agencies and four periods chosen for this study. The first period (1987-1992) summarizes the net official flows to the Congo from U.N. agencies prior to the Rwandan genocide. The second period is related to the Rwandan genocide and the overthrow of Mobutu regime (1993-1997) and the third is the Kabila I regime (19982001). The last period presents the average net official flows during Kabila II regime (2002-2010). As for the food assistance branch of the United Nations, the World Food Program, results suggest that the net official flows average $\$ 2.5$ million in preRwandan genocide, $\$ 28.5$ million during the Rwandan genocide, the violent conflicts in the eastern Congo and the end of Mobutu regime. Funds went down to $\$ 5.3$ million during Kabila I regime and to $\$ 3.94$ million during Kabila II because atrocities were on decline. A similar pattern of the net official flows is observed when looking at the United Nations High Commissioner for Refugees' funds of \$6.1 million, \$19.5 million, \$11 million, and \$7 million, respectively. Notice a steady increase in net official flows to the Congo from the United Nations Development Program and the United Nations Population Fund during the period under analysis. In fact, some of the agencies and their staff have been present in the region for more than two decades. It is reasonable to argue that economic impact of humanitarian operations shall be substantial. Evidence suggests that the real estate market has 
seen a tremendous increase in investments to accommodate the humanitarian operations, the demand for additional housing, dining, and amenity for their staff. Again, wealth created and reinvested locally and the demographic explosion in the region increase the demand for new constructions and for land acquisition or ownership.

To illustrate, humanitarian operations (building refugees' shelters and UN, donors, and NGOs' facilities) have increased the non-vegetation area in the district of Goma. Beyond the U.N. refugee's camps, the local population, other refugees outside the U.N. camps, and the internally displaced persons(IDPs) have contributed to the deforestation and disturbance of the ecosystem balance in the territory of Goma and its periphery in quest for food, wood, cultivation and other resources to support themselves and families. Figure 7 gives a glimpse of the spatial transformation of Goma.

The second economic impact can be to some extent captured from the very conservative estimates of proceeds from the illicit trade of natural resources. Figure 8 summarizes the value of illicit trade of natural resources from a recent report by the United Nations agencies (UNEP-MONUSCO-OSESG, 2015) entitled “Experts' background report on illegal exploitation and trade in natural resources benefitting organized criminal groups and recommendations on MONUSCO's role in fostering stability and peace in eastern DR Congo, final report of April 15th, 2015. (See www.unep.org for a full version of the report). This final report provides the estimated values of illegal exploitation and trade of natural resources by organized criminal groups and rebel groups or armed groups. In such circumstances, even the best attempt to accurately estimate the monetary value of illegal exploitation and trade of natural resources may not be fully successful. A careful consideration is in order given the fact that the U.N. Experts estimate the value of illegal trade of minerals, wildlife, timber, and charcoal at least $\$ 1.25$ billion dollars per annum is what is available to researchers. In other words, using the figures from the World Bank (2018), the value of the illegal exploitation and trade of natural resources represents about 4.24 percent of Congo's Gross Domestic Product (GDP) when expressed in purchasing parity power of constant 2011 international dollars. Wealth created in the region has a real economic impact in the region.

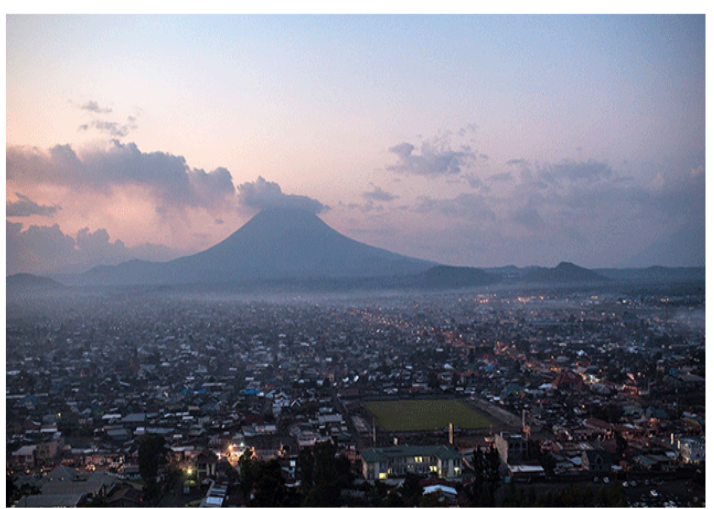

Figure 7: Overview of Goma

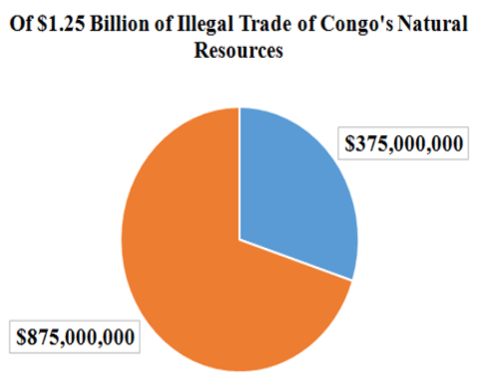

- Transnational organized crime | Local organized crime

Figure 8: Estimated Value of Illegal Trade of Congo's natural resources. Source: UNEP-MONUSCO-OSESG (2015) entitled “Experts' background report on illegal exploitation and trade in natural resources benefitting organized criminal groups and recommendations on MONUSCO's role in fostering stability and peace in eastern DR Congo.

Furthermore, the monies from illegal trade of natural resources could help reach the U.N. goal of "near-zero" deaths from malaria by 2015. As discussed by David Smith of The Guardian ([36]) in an article entitled "Malaria cases surge in Democratic Republic of the Congo: Clinics and treatment centres unable to cope, warns Médecins Sans Frontières amid renewed fighting by militia groups," malaria claims lives of about 300,000 children before their 5 th birthday. It is important to stress that the total budget for the global campaign to fight malaria to nearly zero deaths was estimated at $\$ 3.2$ billion of dollars. Just three years of proceeds from illegal trade of Congo's natural resources could pay for the total bill with an excess of \$ 544 million in hands.

By all measures, the territory of Goma emerges as the third populous city in Congo. It is a common say in Yombe culture, southwest Congo that "a drop of honey attracts more flies than a drop of blood." It has been shown in the human experience that whenever there is a dire situation, people follow safety and opportunities. Based on the population density estimates, Goma is the most populous city in Congo with a population average of 37,620 per square mile followed by Lubumbashi, the economic capital of Congo, with an average of 6,221 per square mile expressed in persons per square mile, and Kinshasa, the capital city, with an average population of 4,437 per square mile, and Kisangani with 1, 270 per square mile. With respect to the land mass, Goma is very small. It represents 1 percent of Kinshasa, 4 percent of Kisangani, and 10 percent of Lubumbashi.

Figure 9 summarizes the results of the bi-temporal spectral change detection in the territory of Goma. The left panel of the figure shows the map of the NDVI of 1987 and the right panel shows the map of the NDVI of 2010. To put these results in context, it is important to describe the relative location of Goma with respect to the Nyiragongo and the Lake Kivu. The mouth of the volcano is located in the bottom portion of the first quadrant if one divides the map shown in figure 9 in four quadrants. Looking west of Nyiragongo Volcano, there is another volcano called Nyamuragira, but not shown here. Some of the lava imprints shown on the west of the territory of Goma are 
from the Nyiragongo and Nyamuragira eruptions. It is also important to note on the right panel of Figure 9 two hotspots. The first is located in the west, which is the area predominantly occupied by farming communities both locals and internally displayed persons. The second is located in the east, which is the area predominantly occupied by the United Nations Higher Commissioner for Refugees (UNCHR) sites for their operations and refugee camps.

Increased economic opportunities, humanitarian operations and the "coltan boom" resulted in higher revenues, and investments in real estate with new constructions, unprecedented population growth driven massive flow of refugees and Internally Displaced Persons (IDPs) altered the spatial structure in the territory of Goma. The driver for this massive displacement of the populations was fear of being killed or being sexually abused or being kept as slaves in places where there was a continued presence of 20 foreign and domestic armed groups as reported by the United Nations Office for the Coordination of Humanitarian

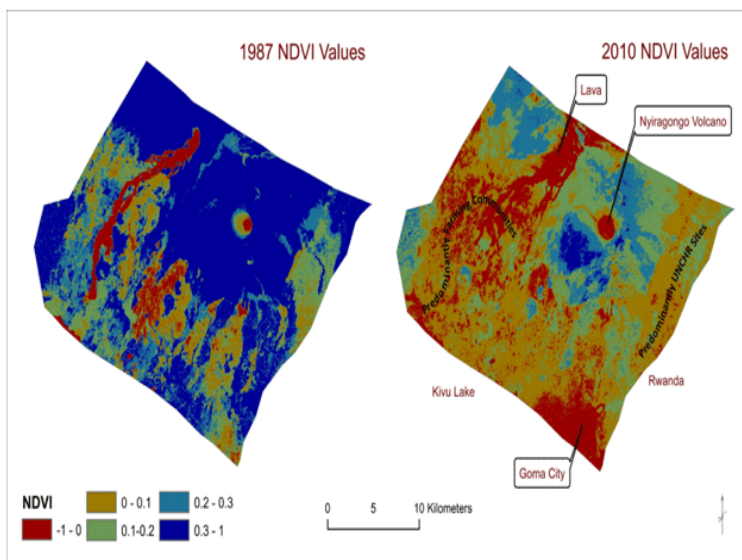

Figure 9: Land cover differences between 1987 and 2010.

Findings are presented using both the co-registration and the geo-linking of the two images side by side and the image algebra for image differencing of the NDVI. Evidence suggests an increase in non-vegetation areas as shown in Figure 9. Results find support from Lunetta, et al. [25]. It is important to note that the area with NDVI values more than 0 in 1987 was 143,582 acres which came down to 129, 976 acres in 2010. Based the difference between these acres, findings indicate an increase of 20,606 acres of nonvegetation areas and are consistent with a study by Tedesco, et al. [38] who note an expansion of the city of Goma northward by refugees from the 1994 Rwandan genocide. As related to the political economy of war, exploitation of valuable minerals in the neighboring territories of Goma (Masisi and Rutshuru) using the traditional trans-border networks makes the district of Goma an important regional trade center and an air hub for export of these ores. Notice reinvestments (mineral rents and wealth created in the region) in real estate and an exceptional population density of 8.5 more than the capital city, Kinshasa, altered the land use and land cover of the territory of Goma.

\section{Conclusions and Discussion}

The main purpose of this study was to provide explanations of the change observed in the land cover and land use in the territory of Goma. The geophysical processes (volcanoes) have been responsible for the land cover mostly in the northwest side of the territory of Goma. Figure 9 documents the impact. Economic opportunities and quest for safety and shelter have attracted many in this territory. The demographic explosion is unprecedented because it is the all-time record in the Congolese history. This study was made possible by using the mixed methods approach. The quantitative portion helps collect and process the data and to produce two maps to document changes in the territory of Goma's landscape. That is, the geospatial technologies (Remote sensing, GIS, and Cartography) provide the means to remotely detect changes in the study area. The qualitative portion of the study provides content and context to the observed changes. The political economy helps understand the conditions from which wealth is created, distributed, and reinvested. The wonder is not such evidence should occur, but it should occur so often in weakly institutionalized polity. This study shows that a better use of the geospatial technologies and the political economy can provide interesting results.

Findings are consistent with Duffield ([14], p.75) who argues that globalization and trade liberalization have helped warring parties to create the parallel and trans-border economic relations for financing and arms supply. Goma was a forgotten territory, a tourism attraction and a frontier town. The political economy of war made Goma a regional trading hub with more economic opportunities with astonishing population growth. Its land cover and land use has dramatically changed due to high demand for mineral resources of the region, humanitarian operations bringing more hard currencies, and the survival strategies of local population, refugees, and internally displaced persons in this war economy. Historical records indicate that exploitation of natural resources in Congo has its roots in the pre-colonial time through network of local elites, and trans-border commercial agents. Overwhelming evidence both in the academic literature and in the popular press underlines the role of mineral as a curse to Congo. A panel of experts of United Nations Security Council 2001 and 2002 reports on the illegal exploitation of natural resources in Congo point to the demand for export of rare resources including gemstones with small weight and high value. Likewise, Rosen ([33]) of The Atlantic laments that:

The conflict in the eastern Democratic Republic of Congo, which I visited over the last week of April, has killed somewhere between 3.5 and 5.4 million people since1996. It destroys human life in crushing and un-cinematic fashion. Its victims live deep in the mountains of central Africa, and despite the efforts of a few intrepid journalists, scholars, and human rights observers, their suffering goes largely undocumented. They include peasant women, who are raped collecting firewood, children dying of cholera in bulging refugee camps, and starving young boys conscripted into militia groups so numerous that experts have trouble keeping track of them all. The DRC's conflict might be the deadliest since World War II, and one of world's worst active 
crises. But it also may be the most obscure -- the most anonymous.

Additionally, in presenting the "The future of Niobium and Tantalum: Worldwide supply and demand, the USGS (2014) reports in fact sheet that:

Fluctuating market conditions as with the recent worldwide economic crisis, interrupted operations at a number of production sites, and future economic instability has the potential to generate supply problems. Other possible descriptions include war, civil unrest, political changes, natural disasters, environmental issues and market manipulation. For example, rebel sales of 'conflict coltan' in the Democratic Republic of Congo, amidst a supplyline transparency and traceability as tools for excluding illegal columbite-tantalite while keeping the market open for legitimate, small-scale artisanal mining in Central Africa.

Despite numerous deaths, seen and undiagnosed posttraumatic disorders, human suffering, Goma has accumulated more wealth and has attracted more people than ever before. On the other hand, the Congo as a whole is deprived of its mineral riches. Overall, this study expands the applicability of the geospatial technologies and the political economy of war. Their mix helps better understand the interplay among transborder trade, valuable minerals and wars and their link to land use and land change use in the region. Further research is needed to accurately measure the land cover and land use changes resulting from wealth creation and that of survival strategies of the poor who shall clear the land for agriculture and for settlement. The future data collection will include true ground control points for field visits when funds will be available and when it will be safe to do so.

\section{Author Biography}

Onyumbe Enumbe B. Lukongo is an assistant professor of economics at Southern University and A\&M College. He is an applied econometrician and expert in geospatial analytics (GIS, spatial econometrics, spatial statistics, cartography, and remote sensing technologies). He is also a principal investigator and a reviewer of both U.S. federal grants and scholarly journals. His familiarity with major databases and geospatial analytics allows him to connect economic or social issues to the context of people and places. Dr. Lukongo belongs to a new generation of economists who leverages mixed methods approach to studying the political economy of development, minerals, and wars.

\section{References}

1. Auch FR, Sayler LK., Napton ED, Taylor LJ, Brooks SM. Ecological Differences in late 20th Century Land Use and Land Cover Change in the U.S. Northern Great Plains. Great Plains Research 21. 2011:231243.

2. Bernard HR. Social Research Methods: Qualitative and Quantitative Approaches. Thousand Oaks, CA: Sage Publications. 2000.

3. Butsic V, Baumann M, Shortland A, Walker S, Kuemmerle T. Conservation and Conflict in the Democratic Republic of Congo: The impacts of Warfare, Mining, and Protected Areas on Deforestation. Biological Conservation. 2015;191:266-273.
4. Campbell BJ, Wynne HR. Introduction to Remote Sensing. 5th Ed. The Guilford Press, New York: NY; 2011.

5. Carr D. Population and Deforestation: Why Rural Migration Matters. Progress in Human Geography. 2009;33(3):355-378.

6. Chang KT. Introduction to Geographic Information System. 5th Ed. New York, NY: The McGraw-Hill Companies Inc; 2010.

7. Collier P. On the Economic Consequences of Civil War. Oxford Economic Papers. 1999;51(1):168-183.

8. Collier P, Hoeffler A. Greed and Grievance in Civil War. Oxford Economic Papers. 2004;56(4):563-595.

9. Creswell WJ, Clark LV. Designing and Conducting Mixed Methods Research. 3rd Ed. Thousand Oaks, CA: Sage Publications. 2018.

10. De Sherbinin A, Balk D, Yager K, Jaiteh M, Pozzi E, Giri C, Wannebo A. A CIESIN Thematic Guide to Social Science Applications of Remote Sensing. Center for International Earth Science Information Network (CIESIN) Columbia University Palisades, NY, USA. 2002.

11. Dena M. Stolen Goods: Coltan and Conflict in the Democratic Republic of Congo. SAIS Review. 2002;22(1):103-118.

12. Dent DB. Cartography: Thematic Map Design. 5th Ed. Boston, MA: The McGraw-Hill Companies Inc; 1999.

13. Draulans D, Van Krunkelsven E. The Impact of War on Forest Areas in the Democratic Republic of Congo. Oryx. 2002;36(1):35-40. doi: 10.1017/S0030605301000011

14.Duffield M. Globalization, Transborder Trade and War Economies. In: Berdal M, Malone DM, Editors. Greed and Grievance: Economic Agendas in Civil Wars. Boulder, CO: Lynne Rienner Publishers; 2000. P. 69-89.

15. Duncan C, Kretz D, Wegmann M, Rabeil T, Pettorelli N. Oil in the Sahara: Mapping Anthropogenic Threats to Saharan Biodiversity from Space. Philos Trans R Soc Lond B Biol Sci. 2014;369(1643):20130191. doi: 10.1098/rstb.2013.0191

16. Easterly W, Levine R. Africa's Growth Tragedy: Policies and Ethnic Divisions. Quarterly Journal of Economics. 1997;112(4):1203-1250.

17. Gallant LA, Loveland RT, Sohl LT, Napton ED. Using an Ecoregion Framework to Analyze Land-cover and Land-use Dynamics. Environmental Management. 2004;34(1):89-110.

18. Gilbrook JM, Weishampel FJ. A Method for Normalizing Classified Land-cover Imagery for Use in Change-detection Analysis. Urban and Regional Information Systems Association Journal. 2015;26(2):5-24.

19. Hayes K, Burge R. Coltan Mining in the Democratic Republic of Congo: How tantalum-using industries can commit to the reconstruction of the DRC. Fauna \& Flora international. 2003.

20. Institute for Environmental Security. Mining, Forest Change and Conflict in the Kivus, Eastern Democratic Republic of Congo. 2008. Available from: http://www.envirosecurity.org/espa/PDF/Mining forest_change_and_conflict_in_the_Kivus.pdf

21. Institute for Environmental Security. Good Deal Bad Deal: Illegal Trade in Natural Resources-What Can Brussels Do? Report of the conference. 2010. Available from: http://www.envirosecurity.org/pathfinder/ conference/Report_Final_med.pdf 
22. Lambin FE, Turner BL, Geista JH, Agbolac BS, Angelsend A, Brucee JW, et al. The Causes of Land Use and Land Cover Change: Moving beyond the Myths. Global environmental change. 2001;11(4):261-269.

23. Le Billion P. The Political Ecology of War: Natural Resources and Armed Conflicts. Political Geography. 2001;20(5):561-584.

24. Lillesand MT, Kiefer WR, Chipman WJ. Remote Sensing and Image Interpretation. 6th Ed. Hoboken, NJ: John Wiley \& Sons Inc; 2008.

25. Lunetta SR, Knight FJ, Ediriwickrema J, Lyon GJ, Worthy LD. Landcover Change Detection using Multi-Temporal MODIS NDVI data. Remote Sensing of Environment. 2006;105(2):142-154.

26. Lv YZ, Shi ZW, Zhou CX, Benediktsson AJ. Semi-Automatic System for Land Cover Change Detection Using Bi-Temporal Remote Sensing Images. Remote Sens. 2017;9(11):1112. doi:10.3390/rs9111112

27. Mill SJ. Principles of Political Economy. Amherst, New York: Great Minds Series Prometheus Books. 2004.

28. Napton ED, Auch FR, Headly R, Taylor LJ. Land Changes and their Driving Forces in the Southeastern United States. Regional Environmental Change. 2010;10(1):37-53.

29. Nzongola-Ntalaja Georges. The Congo from Leopold to Kabila: A People's History. London: United Kingdom: Zed Books. 2002.

30. Olsson O, Fors CH. Congo: The Price of Predation. Journal of Peace Research. 2004;41(3):312-336.

31. Potapov P, Turubanova S, Hansen M, Adusei B...Justice, C. Quantifying Forest Cover Loss in Democratic Republic of Congo, 2000-2009, with Landsat ETM+ data. Remote Sensing Environment. 2012;112:106116.

32. Raleigh C, Hegre H. Population Size, Concentration, and Civil War A Geographically Disaggregated Analysis. Political Geography. 2009;28(4):224-238.

33. Rosen A. The Origins of War in the DRC: How the Region became Overrun by Warlords and Lacking any Kind of Functional Government. 2013.

34. Ross LM. What Do We Know about Natural Resources and Civil War? Journal of Peace Research. 2004;41(3):337-356.

35. Ross LM. Oil, Drugs, and Diamonds: How Do Natural Resources Vary in their Impact on Civil War? The International Peace Academy Project on economic agendas in civil wars. 2002:1-37.

36. Smith D. Malaria cases surge in Democratic Republic of the Congo: Clinics and treatment centres unable to cope, warns Médecins Sans Frontières amid renewed fighting by militia groups, The Guardian. 2012.

37. Synder R, Bhavnani R. Diamonds, Blood, and Taxes: A revenuecentered framework for explaining political order. Journal of Conflict Resolution. 2005;49(4):563-597.

38. Tedesco D, Vaseli O, Papale P, Carn SA, Voltaggio M, Sawyer GM, et al. January 2002 Volcanic-tectonic eruption of Nyiragongo Volcano, Democratic Republic of Congo. Journal of Geophysical Research. 2007;112:1-12
39. Thurston J, Poiker KT, Moore PJ. Integrated Geospatial Technologies: A Gide to GPS, GIS, and Data Logging. John Wiley \& Sons, Inc. Hoboken, NJ. 2003.

40. Turner T. Congo. Cambridge, UK: Polity Press. 2013.

41.U.S Department of the Interior U.S. Geological Survey. Landsat 7 Program Report. 2000.

42. U.S. Fish \& Wildlife Service. A Results-Based Vision for Conservation in Central Africa. 2015.

43. UN Office for the Coordination of Humanitarian Affairs (UN OCHA). Regional Humanitarian Update. 2007;1(5).

44. United Nations Education, Scientific and Cultural Organization. Convention Concerning the Protection of the World Cultural and Organization Convention Concerning the Protection of the World Cultural and Natural Heritage World Heritage Committee Twentyseventh session Paris, UNESCO Headquarters, State of conservation of properties inscribed on the List of World Heritage in Danger and on the World Heritage List. 2003.

45. United Nations High Commissioner for Refugees. Statistical Yearbook Annex Tables 1-28. 2009.

46. US. Department of the Interior U.S. Geological Survey. Niobium and Tantalum-Indispensable Twins. 2014.

47. Vlassenroot K, Büscher K. The city as Frontier: Urban Development and Identity Processes in Goma. Crisis States Working Papers Series No.2 Working Paper no. 61 Cities and Fragile States Conflict Research Group, University of Ghent. 2009.

48. Wallensteen P, Sollenberg M. Armed Conflict Complexes, 1989-97. Journal of Peace Research. 1998;35(8):621-634.

49. Wallensteen P, Sollenberg M. Armed Conflict, 1989-2000. Journal of Peace Research. 2001;38(5):629-644.

50.Weidmann BN. Geography as Motivation and Opportunity: Group concentration and ethnic conflict. Journal of Conflict Resolution. 2009;53(4):526-543.

51. Wingate RV, Phinn RS, Kuhn N, Lena Bloemertz L, Kiran LD. Mapping Decadal Land Cover Changes in the Woodlands of North Eastern Namibia from 1975 to 2014 Using the Landsat Satellite Archived Data. Remote Sens. 2016;8(8):681. doi:10.3390/rs8080681

52.Yu Q Epstein EH, Engstrom R, Shiklomanov N, Strelestskiy D. Land cover and land use changes in the oil and gas regions of Northwestern Siberia under changing climatic conditions. Environmental Research Letters. 2015;10(12):1-13. doi:10.1088/1748-9326/10/12/124020

53.Zaidi MS, Akbari A, Samah AA, Kong NS, Aanak Gisen JI. Landsat-5 Time Series Analysis for Land Use/Land Cover Change Detection Using NDVI and Semi-Supervised Classification Techniques. Pol J Environ Stud. 2017;26(6):2833-2840. doi: 10.15244/pjoes/68878 